\title{
KARAKTERISTIK FISIK TEPUNG TEH HIJAU YANG DIPROSES MENGGUNAKAN DISC MILL DAN STONE MILL
}

\author{
[Physical Characteristics of Green Tea Powder Processed \\ by Disc and Stone Mills]
}

\section{Iqbal Prawira-Atmaja*, Shabri, Sugeng Harianto, Hilman Maulana, dan Dadan Rohdiana}

Departemen Pengolahan Hasil dan Enjineering, Pusat Penelitian Teh dan Kina, Gambung, Bandung

Diterima 19 Februari 2018 / Disetujui 28 Mei 2018

\begin{abstract}
Size reduction could affect the physical properties of green tea powder. The aim of this study was to determine the physical properties of green tea powder processed by different milling methods. A disc mill (DM) with single screw made from stainless steel and a stone mill (SM) made from granite stone were used to produce green tea powder. Water holding capacity, water solubility index, swelling capacity, wettability, extraction yield, dispersibility and dispersion stability, and particle size distribution were analyzed to determine the physical properties of green tea powder. The morphology and shape of green tea powder were also observed using scanning electron microscopy. The DM method produced green tea powder with higher values of water absorption index, swelling capacity and water holding capacity, i.e. $4.57 \mathrm{~g} / \mathrm{g} ; 5.17 \mathrm{~mL} / \mathrm{g}$; and $6.18 \mathrm{~g} / \mathrm{g}$ respectively. Green tea powder with SM method had a brighter color with $L$ value of 60.1 and was a fine powder with $d_{50}$ of $1.4 \mu \mathrm{m}$. Based on the above physical properties, green tea powder with SM milling method is more suitable for application in food products.
\end{abstract}

Keywords: green tea powder, milling methods, particle size, physical properties

\begin{abstract}
ABSTRAK
Penelitian ini dilakukan untuk mengetahui karakteristik sifat fisik tepung teh hijau yang diproses dengan metode penepung berbeda. Disc mill (DM) dengan single screw berbahan dasar stainless steel dan stone mill (SM) berbahan dasar batu granit digunakan untuk menepungkan teh hijau. Water holding capacity, water solubility index, swelling capacity, wettability, extraction yield, dispersibility dan dispersion stability, dan ukuran distribusi partikel dianalisis untuk mengetahui sifat fisik tepung teh hijau. Morfologi dan bentuk tepung teh hijau juga diamati menggunakan scanning electron microscopy. Metode penepung DM menghasilkan tepung teh hijau dengan nilai water absorption index, swelling capacity, dan water holding capacity lebih tinggi jika dibandingkan dengan metode penepung SM, dimana secara berurutan nilainya adalah $4,57 \mathrm{~g} / \mathrm{g} ; 5,17 \mathrm{~mL} / \mathrm{g}$; dan $6,18 \mathrm{~g} / \mathrm{g}$. Tepung teh hijau yang diproses dengan metode SM memiliki warna lebih cerah dengan nilai $L: 60,1$ dengan ukuran partikel tepung teh hijau $d_{50}: 1,4 \mu \mathrm{m}$. Berdasarkan sifat fisik tersebut, tepung teh hijau yang diproses dengan metode SM lebih sesuai jika diaplikasikan untuk produk pangan.
\end{abstract}

Kata kunci: metode penepungan, sifat fisik, tepung teh hijau, ukuran partikel

\section{PENDAHULUAN}

Teh (Camellia sinensis) merupakan minuman yang memiliki banyak manfaat kesehatan seperti anti virus herpes (de Oliveira et al., 2015), pencegah kanker kolon (Hajiaghaalipour et al., 2015), menghambat aktivitas enzim Xhantin oksidase penyebab asam urat (Rohdiana et al., 2014), dan mengurangi efek sindrom metabolik dan diabetes tipe 2 (Henning

\footnotetext{
*Penulis Korespondensi:

E-mail: iqbalprawira06@gmail.com
}

et al., 2017). Manfaat kesehatan tersebut dikarenakan senyawa bioaktif seperti katekin pada teh hijau (Braicu et al., 2013) atau theaflavin dan thearubigin pada teh hitam (Sharangi et al., 2014).

Teh berdasarkan prosesnya terdiri atas teh hitam, oolong, dan teh hijau. Diantara jenis teh tersebut, teh hijau paling banyak digunakan dalam industri pangan. Teh hijau menurut SNI 3945:2016 memiliki ukuran partikel antara 2-20 mm. Teh hijau dengan ukuran seperti itu sangat sulit diaplikasikan pada produk pangan. Pengecilan ukuran teh hijau dibutuhkan supaya bisa lebih mudah diaplikasikan 
baik untuk proses ekstraksi maupun sebagai produk pangan (Komes et al., 2010). Salah satu produk pengecilan ukuran teh hijau adalah matcha, tepung teh hijau dari Jepang. Matcha merupakan tepung teh hijau yang umumnya digunakan dalam upacara tradisional di Jepang. Matcha diproduksi dari daun teh dengan perlakuan naungan untuk meminimalisir sinar matahari (Hirai et al., 2008) kemudian dilayukan dengan uap panas (inaktivasi enzim), dikeringkan, dan ditepungkan sehingga dihasilkan tepung teh hijau yang lebih seragam (Topuz et al., 2014) dan lebih mudah diaplikasikan ke produk pangan seperti es krim (Kavaz-Yüksel et al., 2017).

Proses penepungan merupakan tahapan penting untuk menghasilkan produk tepung teh. Banyak penelitian yang melaporkan berbagai metode penepung untuk menghasilkan tepung teh hijau. Penelitian oleh Haraguchi et al. (2003) dengan menggunakan metode jet milling dan ball milling untuk memproduksi tepung teh hijau. Penelitian lebih lanjut dilakukan oleh Pandey dan Manimehalai (2014) menggunakan teknologi spray drying untuk menghasilkan bubuk teh sedangkan Zokti et al. (2016) memanfaatkan teknologi mikroenkapsulasi untuk menghasilkan tepung teh hijau. Penggunaan berbagai jenis metode penepungan akan dihasilkan karakteristik fisik, morfologi, kemampuan dispersi tepung teh, dan senyawa kimia yang berbeda (Xiao et al., 2017). Namun, keseluruhan teknologi penepung teh hijau tersebut belum bisa dioptimalkan pemanfaatannya di Indonesia karena dirasa masih terlalu mahal. Banyak petani teh rakyat masih menggunakan metode disc milling (DM) di dalam memproduksi tepung teh hijau.

Metode DM berdasarkan pada prinsip kerja gesekan antar sampel dengan gaya tekanan dari ulir sehingga menghasilkan tepung dengan ukuran kecil (Barbosa-Canovas et al., 2005). Metode DM bekerja dengan gaya putaran tinggi yang membutuhkan energi besar, sehingga dapat memengaruhi penampakan dan sifat fisikokimia tepung akibat panas yang dihasilkan dari gesekan (Fitzpatrick, 2013). Alternatif proses penepungan salah satunya adalah penggunaan material alam seperti batu untuk menghasilkan tepung teh hijau berkualitas. Fujioka et al. (2016) menggunakan bahan keramik (ceramic milling) untuk penepung teh hijau sehingga dihasilkan tepung teh hijau berukuran partikel $15 \mu \mathrm{m}$. Hingga kini masih sedikit penelitian yang melaporkan penggunaan batu alam untuk menghasilkan tepung teh hijau. Berdasarkan informasi di atas, maka penelitian ini bertujuan untuk mengetahui perbedaan sifat fisik tepung teh hijau yang dihasilkan dari metode penepungan disc mill (DM) dengan metode penepungan stone mill (SM), serta bentuk morfologi tepung teh juga diamati untuk mengetahui pengaruh perbedaan metode penepungan tersebut.

\section{BAHAN DAN METODE}

\section{Bahan}

Daun teh (Camellia sinensis var. Asamica) dari klon GMB 9 yang terdiri atas pucuk dan 3 daun muda $(P+3)$ dipetik secara manual dengan tangan di Kebun Percobaan Pusat Penelitian Teh dan Kina (PPTK) Gambung, Kabupaten Bandung, Jawa Barat, Indonesia.

\section{Pengolahan teh hijau}

Daun teh yang telah dipetik kemudian diolah di laboratorium mini-processing pengolahan teh hijau yang berada di Laboratorium Pengolahan \& Pengujian Mutu Teh PPTK. Tahap pengolahan teh hijau meliputi, inaktivasi enzim dengan uap panas $(2,5$ menit; $100^{\circ} \mathrm{C}$ ), proses pencacahan menggunakan mesin CTC (CNC, Srilanka), dan pengeringan menggunakan rack drier (CNC, Srilanka) pada suhu $85^{\circ} \mathrm{C}$ selama 60 menit hingga diperoleh produk teh hijau kering (kadar air 2-5\%). Produk kering kemudian digunakan sebagai bahan baku untuk pembuatan tepung teh hijau. Teh hijau kering selanjutnya disimpan dalam wadah plastik tertutup hingga akan digunakan sebagai bahan baku untuk pembuatan tepung teh hijau. Proses pengolahan teh hijau dilakukan sebanyak tiga kali ulangan dengan waktu petik yang berbeda.

\section{Persiapan penepungan teh hijau}

Penelitian ini menggunakan 2 jenis tipe mesin penepung untuk menghasilkan tepung teh hijau sebagai variabel bebas. Tipe mesin penepung yang digunakan adalah tipe mesin Disc mill dan tipe mesin Stone mill. Proses pengolahan tepung dilakukan sebanyak tiga kali ulangan. Persiapan penepungan teh hijau dilakukan dengan alat penepung disc milling (DM) dan stone milling (SM). Disc mill (Indonesia) memiliki bagian single screw berbahan dasar logam stainless steel yang digerakkan oleh mesin tipe JY09A-4 Jy Series Single Phase $(0.18$ kw, $0.25 \mathrm{HP}$ ) dengan kecepatan $1400 \mathrm{rpm}$. Teh kering dimasukkan melalui wadah corong dan akan kontak dengan screw hingga dihasilkan tepung teh hijau. Proses ini diulang sekali sehingga menghasilkan tepung teh hijau yang halus. Tipe pertama ini banyak digunakan oleh petani teh rakyat di Jawa Barat untuk menghasilkan tepung teh hijau.

Tipe kedua adalah stone mill (SM) berbahan dasar batu granit yang terdiri atas dua lapis yang saling berhimpitan dengan diameter $90 \mathrm{~cm}$, tebal 45 $\mathrm{cm}$. Batu granit pada lapisan atas akan berputar searah jarum jam dengan kecepatan $13 \mathrm{rpm}$, sementara itu batu granit di lapisan bawah dalam kondisi tidak bergerak (statis). Teh hijau dimasukkan melalui corong pada bagian atas batu granit yang berputar. Produk tepung teh hijau akan keluar melalui celahcelah kecil diantara dua lapisan batu. Tepung teh 
hijau selanjutnya disimpan pada kemasan plastik gelap dengan lapisan alumunium foil untuk meminimalisir paparan cahaya secara langsung dan disimpan pada wadah tertutup dengan relative humidity $<60 \%$ untuk dianalisis lebih lanjut.

\section{Analisis sifat fisik tepung teh hijau}

Analisis sifat fisik tepung teh hijau meliputi: kadar air tepung teh hijau yang mengacu pada ISO 1572; bulk density (Sakurai et al., 2017) dan warna tepung teh hijau dianalisis menggunakan metode Hunter LAB Cromameter (CR 4000, Conica Minolta, Jepang). Morfologi tepung teh hijau diamati menggunakan Scanning Electron Microscopy (SEM) (FEI, type Inspect S50, Jepang) dengan pembesaran 200x dan 500x. Analisis ukuran partikel tepung teh hijau dianalisis menggunakan Delsa ${ }^{\mathrm{TM}}$ Nano (Beckman Coulter, USA) dengan metode dynamic laser scaterring dimana air deionisasi digunakan sebagai media dispersi untuk pengukuran ukuran distribusi partikel. Ukuran partikel dihitung berdasarkan relative width $(\mathrm{Rw})$ berdasarkan rumus:

$R w=\left(d_{90}-d_{10}\right) / d_{50}$

Dimana, $d_{10}, d_{50}$, and $d_{90}$ adalah 10,50 , dan $90 \%$ dari tipe distribusi ukuran partikel.

\section{Analisis sifat hidrasi tepung teh hijau}

Analisis sifat hidrasi tepung teh hijau meliputi: water holding capacity (WHC), water solubility index (WSI), dan swelling capacity (SC) yang mengacu pada metode Zhang et al. (2012) sedangkan water absorption index (WAI) mengacu pada metode Cuevas-Rodriguez et al. (2004) dimana prosedur pengujiannya sebagai berikut.

Analisis water holding capacity (WHC) yaitu 0,5 g tepung teh hijau dimasukkan ke dalam tabung plastik dan ditambahkan akuades dengan rasio tepung/akuades adalah 0,05/1 (b/b). Dispersi tepung selanjutnya diinkubasi di waterbath suhu $60^{\circ} \mathrm{C}$ selama 30 menit dan didinginkan segera mungkin pada air dingin sebelum disentrifugasi dengan kecepatan 5000 rpm selama 20 menit. Supernatan dipisahkan dan selanjutnya endapan ditimbang beratnya. WHC dihitung berdasarkan rumus:

\section{WHC $(g / g)=$ Berat endapan/berat sampel}

Water solubility index (WSI) dianalisis dengan cara tepung teh hijau dilarutkan dengan akuades pada tabung sentrifuse dengan rasio tepung teh hijau/akuades adalah 0,02/1 (b/b). Larutan suspensi selanjutnya diinkubasi di waterbath suhu $80^{\circ} \mathrm{C}$ selama 30 menit dan dilanjutkan dengan sentrifugasi 6000 rpm selama 10 menit. Supernatan secara perlahan dipindahkan ke dalam cawan petri yang telah diketahui beratnya dan dikeringkan pada suhu 103 $\pm 2^{\circ} \mathrm{C}$ hingga diperoleh berat cawan konstan. WSI dihitung berdasarkan rumus:

WSI $(\%)=$ residu pada cawan/berat sampel $\times 100 \%$

Water absorption index (WAI) tepung teh hijau dianalisis dengan cara tepung teh hijau (2,5 g) dilarutkan denga $30 \mathrm{~mL}$ akuades pada tabung centrifuse. Suspensi tepung selanjutnya diaduk dengan magnetik stirer selama 5 menit dan dilanjutkan dengan sentrufgasi selama 10 menit dengan kecepatan 3000 rpm dan supernatan kemudian dipisahkan. WAI dihitung berdasarkan berat endapan yang tersisa per berat tepung.

Swelling capacity (SC) tepung teh hijau dilakukan dengan cara menimbang $1 \mathrm{~g}$ tepung teh hijau didalam wadah tabung sentrifuse sehingga diketahui volume awalnya. Tepung teh hijau dan kemudian ditambahkan $10 \mathrm{~mL}$ akuades dan dikocok hingga tercampur merata. Suspensi tepung teh hijau selanjutnya diinkubasi pada waterbath suhu $25^{\circ} \mathrm{C}$ selama 24 jam hingga diperoleh pengembangan tepung yang sempurna. Catat penambahan volume tepung teh hijau pada tabung sentrifuse. SC dihitung berdasarkan rumus:

SC $(\mathrm{mL} / \mathrm{g})=$ Vol akhir-vol awal/berat sampel

Analisis wettability tepung teh hijau mengacu pada Park et al. (2001) dimana dan extraction yield tepung teh hijau (Topuz et al., 2014). Kemampuan terdispersi (dispersibility) dan kestabilan dispersi (dispersion stability) tepung teh hijau diukur berdasarkan metode Sakurai et al. (2017) menggunakan spektrofotometer UV-vis (Varian Carry win UV) dengan panjang gelombang $650 \mathrm{~nm}$.

\section{Analisis data}

Setiap analisis dilakukan tiga kali pengulangan dimana data yang diperoleh selanjutnya dilakukan analisis statistik menggunakan metode $t$-test dengan nilai $P<0,05$. Seluruh data dianalisis menggunakan perangkat lunak XLSTAT 2014 (Addinsoft, New York, USA) sebagai $A d d$-ins di Microsoft ${ }^{(}$excel 2013.

\section{HASIL DAN PEMBAHASAN}

\section{Ukuran partikel dan bulk density tepung teh hijau}

Ukuran partikel tepung teh hijau dihitung berdasarkan volume $d_{50}$ yaitu volume diameter rerata tepung teh hijau yang setara pada 50\% kumulatif volume. Tabel 1 menunjukkan bahwa metode penepung SM menghasilkan ukuran partikel tepung teh hijau lebih kecil dan halus $\left(d_{50}: 1,4 \mu \mathrm{m}\right)$ jika dibandingkan dengan ukuran partikel tepung teh hijau de- 
ngan metode penepung DM $\left(d_{50}: 38,6 \mu \mathrm{m}\right)$. Hasil tersebut menunjukkan bahwa metode alat penepung teh hijau berpengaruh terhadap ukuran partikel tepung teh hijau yang dihasilkannya.

Tabel 1. Pengaruh alat penepungan terhadap bulk density dan ukuran partikel tepung teh hijau

\begin{tabular}{lcc}
\hline \multirow{2}{*}{ Parameter } & \multicolumn{2}{c}{ Alat Penepung } \\
\cline { 2 - 3 } & $\mathrm{SM}$ & $\mathrm{DM}$ \\
\hline Kadar air $(\%)$ & $2,6 \pm 0,35^{\mathrm{a}}$ & $1,27 \pm 0,23^{\mathrm{a}}$ \\
Bulk density $(\mathrm{g} / \mathrm{mL})$ & $0,43 \pm 0,01^{\mathrm{a}}$ & $0,37 \pm 0,02^{\mathrm{a}}$ \\
Ukuran partikel & & \\
$\mathrm{d}_{10}(\mu \mathrm{m})$ & $1,5^{\mathrm{a}}$ & $34,1^{\mathrm{b}}$ \\
$\mathrm{d}_{50}(\mu \mathrm{m})$ & $1,4^{\mathrm{a}}$ & $38,6^{\mathrm{b}}$ \\
$\mathrm{d}_{90}(\mu \mathrm{m})$ & $1,58^{\mathrm{a}}$ & $43,7^{\mathrm{b}}$ \\
Relative width & $0,057^{\mathrm{a}}$ & $0,249^{\mathrm{b}}$ \\
\hline
\end{tabular}

Keterangan: Data \pm standar deviasi dari tiga ulangan. Angka yang diikuti huruf yang sama pada baris yang sama menunjukkan tidak berbeda nyata pada uji t-test $\mathrm{P}=0,05 . \mathrm{SM}=$ Stone miller; $\mathrm{DM}=$ Disc miller. $\mathrm{d}_{10}, \mathrm{~d}_{50}$ dan d $_{90}$ adalah 10,50 , dan $90 \%$ dari tipe distribusi ukuran partikel

Ukuran partikel tepung merupakan hal penting pada produk tepung dikarenakan akan berhubungan dengan bentuk partikel dan sifat fisik kima tepung. Ukuran yang lebih kecil pada tepung teh hijau dari tipe mesin penepung stone milling dikarenakan perputaran rpm mesin yang rendah serta area kontak tepung dengan batu yang lebih lama jika dibandingkan dengan tipe penepung disc mill. Penggunaan tipe penepung berbeda akan dihasilkan ukuran partikel tepung teh yang berbeda-beda. Penelitian oleh Fujioka et al. (2016) untuk menghasilkan tepung teh hijau menggunakan ceramics miller dan ball miller dihasilkan tepung teh hijau dengan ukuran partikel berkisar 15,01 $\mu \mathrm{m}$ dan 23,03 $\mu \mathrm{m}$

Menurut Haraguchi et al. (2003) ukuran partikel tepung teh hijau matcha yang halus memiliki kisaran yaitu 1-20 $\mu \mathrm{m}$ sedangkan menurut $\mathrm{Hu}$ et al. (2012) tepung teh hijau yang ideal memiliki ukuran $d_{50}$ 13,5$20,3 \mu \mathrm{m}$. Ukuran partikel yang lebih kecil pada tepung teh hijau lebih diharapkan dikarenakan luas area permukaan yang lebih besar serta keseragaman ukuran partikelnya sehingga lebih mudah di aplikasikan pada berbagai jenis produk pangan maupun produk farmasi. Menurut Haraguchi et al. (2003) ukuran partikel yang halus dari tepung teh akan meningkatkan warna dari mie soba dan akan meningkatkan daya kembang adonan roti. Selain itu, penambahan tepung teh hijau pada roti sebanyak $1 \%$ sangat efektif meningkatkan aktivitas antioksidan mengurangi produksi peroksida selama penyimpanan roti (Ning et al., 2017) dan menjaga kualitas roti selama proses pemanggangan roti (Pasrija et al., 2015).

Tabel 1 menunjukkan bahwa metode penepung berpengaruh signifikan terhadap bulk density tepung teh hijau yang dihasilkannya. Tepung teh hijau yang diproses dengan metode SM memiliki nilai bulk density lebih besar $(0,43 \mathrm{~g} / \mathrm{mL})$ jika dibandingkan tepung teh hijau yang diproses dengan metode penepung DM $(0,37 \mathrm{~g} / \mathrm{mL})$. Penelitian oleh Topuz et al. (2014) bulk density tepung teh hijau berkisar antara $0,58-0,61 \mathrm{~g} / \mathrm{mL}$. Pengukuran bulk density berdampak pada nilai ekonomis yang mana berhubungan dengan ukuran kemasan, transportasi dan kemudahan penyimpanan (Lumay et al., 2012).

\section{Bentuk morfologi tepung teh hijau}

Morfologi tepung teh hijau diamati menggunakan scanning electron microscopy (SEM) dengan perbesaran 200x dan 500x. Gambar 1 menunjukkan bahwa bentuk morfologi tepung teh hijau dipengaruhi oleh metode penepung yang digunakan. Metode penepung SM (B1 dan B2, Gambar 1) dihasilkan partikel tepung teh hijau dengan ukuran kecil yang seragam sehingga dihasilkan tepung teh hijau yang lebih halus dan lembut.
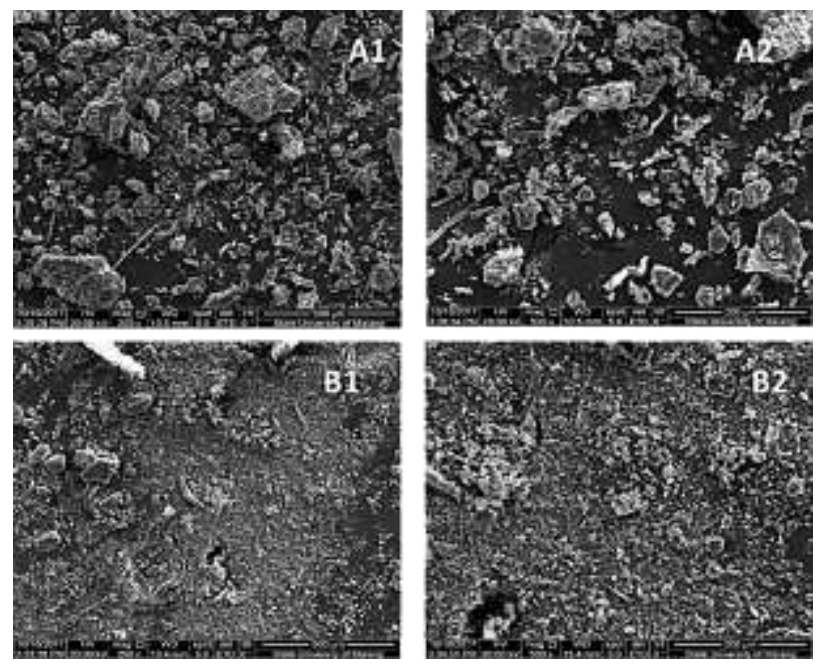

Keterangan: $\mathrm{A} 1$ dan $\mathrm{A} 2$ metode penepung $\mathrm{DM}$ pada perbesaran 200x dan 500x; B1 dan B2 metode penepung SM menggunakan perbesaran 200x dan perbesaran 500x

Gambar 1. Penampakan tepung teh hijau yang dihasilkan dengan alat penepung berbeda menggunakan Scanning electron microscopy

Ukuran partikel tepung teh hijau dengan metode penepung DM Jika dibandingkan dengan metode penepung SM memiliki ukuran partikel cenderung lebih besar dengan rongga rongga pada lapisan permukaan tepung teh hijau. Metode penepung DM juga dihasilkan bentuk dan ukuran tepung teh hijau yang tidak seragam dengan bentuk persegi, lonjong, atau bulat. Ukuran yang lebih halus pada alat penepung SM dikarenakan luas gesekan yang lebih besar dan merata selama proses penepungan teh hijau. Hal ini sesuai dengan penjelasan sebelumnya 
pada Tabel 1 yang mana tepung teh hijau dengan metode penepung SM memiliki ukuran partikel $d_{50}$ : $1,4 \mu \mathrm{m}$.

\section{Warna tepung teh hijau}

Warna merupakan parameter utama pada tepung yang akan berdampak pada persepsi penerimaan konsumen (Murtini et al., 2016). Tabel 2 menunjukkan bahwa metode penepungan yang berbeda dihasilkan kecerahan warna (nilai L) yang berbeda.

Tabel 2. Pengaruh alat penepungan terhadap sifat nilai warna tepung teh hijau

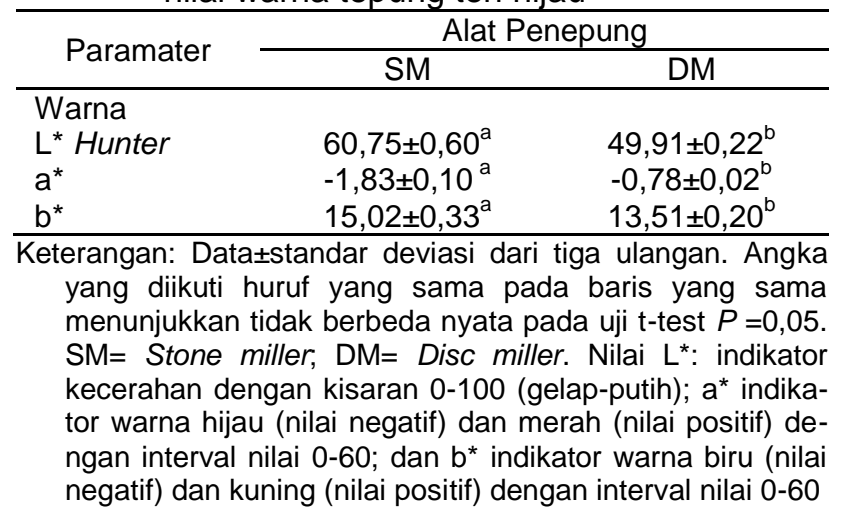

Tepung teh hijau dengan metode penepungan SM memiliki nilai $L$ lebih tinggi dibandingkan dengan tepung teh hijau metode penepungan DM yang mana secara berurutan nilainya adalah 60,75 dan 49,9 . Hal itu menunjukkan bahwa metode SM menghasilkan warna tepung teh hijau lebih cerah. Nilai a yang negatif menunjukkan kecenderungan intensitas warna hijau. Tepung teh hijau yang diproses dengan metode penepung DM dihasilkan warna yang tidak sehijau jika dibandingkan dengan tepung teh hijau dengan metode SM. Nilai kecerahan yang rendah pada tepung teh hijau dengan metode DM dikarenakan adanya peningkatan suhu akibat gesekan kecepatan tinggi dari screw dari mesin penepung.

Ukuran partikel tepung teh hijau turut berpengaruh terhadap kecerahan warna tepung teh hijau. Menurut $\mathrm{Hu}$ et al. (2012) semakin kecil ukuran partikel tepung teh hijau akan meningkatkan nilai kecerahan (L) dan menurunkan nilai warna hijau (-a) dari tepung teh hijau. Warna tepung teh hijau banyak dipengaruhi oleh beberapa faktor diantaranya: waktu pemetikan teh, jenis klon teh, dan cara budiaya agronomi tanaman teh (Topuz et al., 2014); penggunaan mesin/alat penepung (Zhang et al., 2012) dan lama waktu penepungan (Ramachandraiah dan Chin, 2016).

\section{Sifat hidrasi tepung teh hijau}

Pengujian sifat hidrasi tepung teh hijau meliputi WAI, WHC, WSI, wetting time, dan SC. Tabel 3 me- nunjukkan perbedaan nilai sifat hidrasi tepung teh hijau dengan metode penepung berbeda. Tepung teh hijau dengan metode penepung SM memiliki sifat hidrasi yang lebih kecil pada sifat WAI, SC, dan WHC dengan nilai $3,05 \mathrm{~g} / \mathrm{g} ; 3,25 \mathrm{~mL} / \mathrm{g}$ dan $4,05 \mathrm{~g} / \mathrm{g}$ jika dbandingkan dengan tepung teh hijau dengan metode penepung DM dimana nilainya secara berurutan adalah $4,57 \mathrm{~g} / \mathrm{g} ; 5,17 \mathrm{~mL} / \mathrm{g}$ dan $6,18 \mathrm{~g} / \mathrm{g}$.

Tabel 3. Pengaruh alat penepungan terhadap sifat hidrasi tepung teh hijau

\begin{tabular}{|c|c|c|}
\hline \multirow{2}{*}{ Paramater } & \multicolumn{2}{|c|}{ Alat Penepung } \\
\hline & SM & $\mathrm{DM}$ \\
\hline $\begin{array}{l}\text { Water Absorption Index } \\
(W A I)(g / g)\end{array}$ & $3,05 \pm 0,12^{\mathrm{a}}$ & $4,57 \pm 0,72^{b}$ \\
\hline $\begin{array}{l}\text { Swelling Capacity (SC) } \\
(\mathrm{mL} / \mathrm{g})\end{array}$ & $3,25 \pm 0,32^{a}$ & $5,17 \pm 0,20^{\mathrm{b}}$ \\
\hline $\begin{array}{l}\text { Water Holding Capacity } \\
(W H C)(g / q)\end{array}$ & $4,05 \pm 0,15^{a}$ & $6,18 \pm 0,23^{b}$ \\
\hline $\begin{array}{l}\text { Water Solubillity Index } \\
\text { (WSI) (g/g) }\end{array}$ & $0,48 \pm 0,08^{a}$ & $0,39 \pm 0,02^{b}$ \\
\hline Wetting time (detik) & $29 \pm 6,11^{\mathrm{a}}$ & $5 \pm 2,33^{b}$ \\
\hline Extraction Yield (\%) & $56,67 \pm 2,89^{a}$ & $63,33 \pm 5,77^{b}$ \\
\hline Keterangan: Data \pm stanc & iasi dari tiga & langan. Angk \\
\hline
\end{tabular}

Proses penepungan merupakan proses pengecilan ukuran yang mana ukuran keseragaman dan ukuran partikel berpengaruh terhadap sifat hidrasi tepung (Barbosa-Canovas et al., 2005). Semakin halus tepung yang dihasilkan akan menurunkan sifat hidrasi seperti WHC (Ramachandraiah dan Chin, 2016) hal ini diperkuat oleh Zhang et al. (2012) yang menyatakan bahwa nilai WHC dan SC berkorelasi positif dengan ukuran partikel. Selain itu nilai solubilitas tepung teh hijau akan berpengaruh terhadap kestabilan buih (foam) dari tepung teh hijau dikarenakan adanya interaksi gabungan unsur terlarut dari tepung teh hijau (Sawamura et al., 2012).

Metode penepungan DM menghasilkan tepung teh hijau yang cepat menyerap air dengan nilai nilai wetting time lebih cepat yaitu sekitar 5 detik jika dibandingkan dengan tepung teh hijau yang diproses dengan metode SM (29 detik). Wetting time didefinisikan sebagai waktu (detik) yang dibutuhkan tepung sehingga benar benar basah dan tidak ada di atas permukaan cairan (Schuck et al., 2012). Tepung teh hijau dari metode penepung DM lebih cepat karena ukuran partikel yang lebih besar (Tabel 1) serta bentuk morfologi tepungnya yang banyak berongga (Gambar 1) sehingga mampu menyerap air lebih cepat sebagaimana nilai WAI yang lebih besar (Tabel 2). Secara keseluruhan kedua metode penepung menghasilkan tepung teh hijau dengan kriteria sangat mudah basah dikarenakan nilai wetting time dibawah 30 detik (Schuck et al., 2012). 


\section{Dispersibilitas dan kestabilan dispersi tepung teh hijau}

Dispersibilitas tepung adalah kemampuan tepung untuk menyebar merata hingga ukuran terkecil di dalam larutan (Schuck et al., 2012). Gambar 2 menunjukkan kemampuan terdispersi tepung teh hijau yang dihasilkan dengan alat penepung berbeda. Kemampuan terdispersi tepung teh hijau diukur berdasarkan nilai absorbansi pada panjang gelombang $650 \mathrm{~nm}$ menggunakan spektrofotometer UVvis pada menit ke 3, 5, dan 10 .

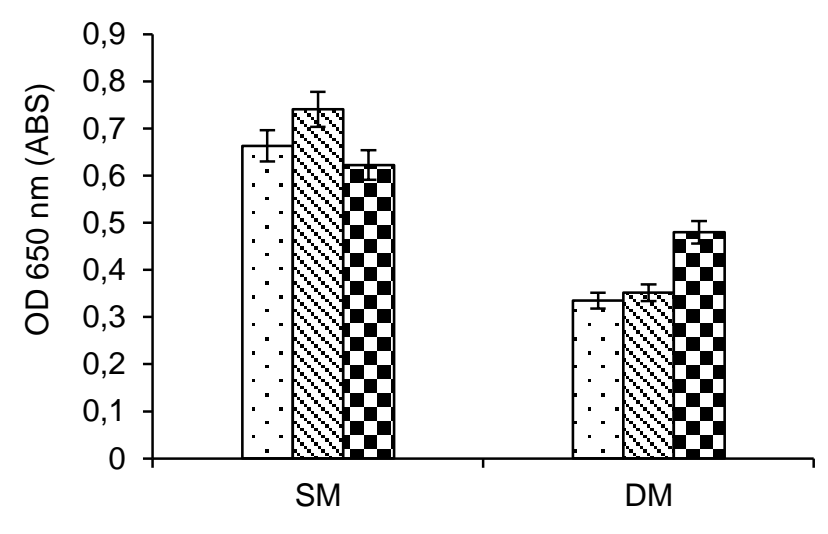

Keterangan: $\mathrm{SM}=$ Stone miller; $\mathrm{DM}=$ Disc miller

Gambar 2. Kemampuan terdispersi tepung teh hijau pada tipe alat penepung yang berbeda terhadap perubahan waktu

Metode penepung SM menghasilkan tepung teh hijau yang memiliki kemampuan terdispersi lebih tinggi jika dibandingkan dengan tepung teh hijau dengan metode penepung DM. Tepung teh hijau dengan metode penepung SM memiliki nilai $O D \geq 0,6$ pada panjang gelombang $650 \mathrm{~nm}$ pada menit ke 3 dan ke 5. Tepung teh hijau dengan metode SM hanya membutuhkan waktu 5 menit untuk bisa terdispersi merata pada larutan akuades sedangkan tepung teh hijau dengan metode penepung DM membutuhkan waktu hingga 10 menit. Secara keseluruhan, nilai absorbansi dari tepung teh hijau dengan metode penepung DM masih lebih kecil (nilai OD $\leq$ $0,5)$ jika dibandingkan dengan nilai absorbansi tepung teh hijau metode penepung SM pada menit ke 3, 5, maupun 10. Menurut Park et al. (2001) tingginya nilai kemampuan terdispersi dikarenakan tepung dengan ukuran partikel lebih kecil akan mudah terdispersi merata dibandingkan partikel berukuran besar. Hasil ini sesuai dengan Tabel 1 dimana ukuran partikel tepung teh hijau yang diproses dengan metode penepung SM lebih kecil yaitu $d_{50}: 1,4 \mu \mathrm{m}$.

Gambar 3 menunjukkan kestabilan dispersi tepung teh hijau dengan metode penepung yang berbeda. Metode SM memiliki kestabilan dispersi tepung teh hijau dengan nilai $O D \geq 0,6$ sedangkan metode DM menghasilkan nilai $\mathrm{OD} \leq 0,4$ pada menit ke-3, 5 dan 10 (Gambar 3A). kestabilan dispersi tepung teh hijau berkaitan dengan nilai indeks solubilitas (Schuck et al., 2012). Tepung teh hijau dengan metode penepung SM memiliki nilai solubilitas 0,48 $\mathrm{g} / \mathrm{g}$ (Tabel 1). Kestabilan dispersi juga berkaitan dengan ukuran partikel dan nilai relative width tepung teh hijau (Sakurai et al., 2017).
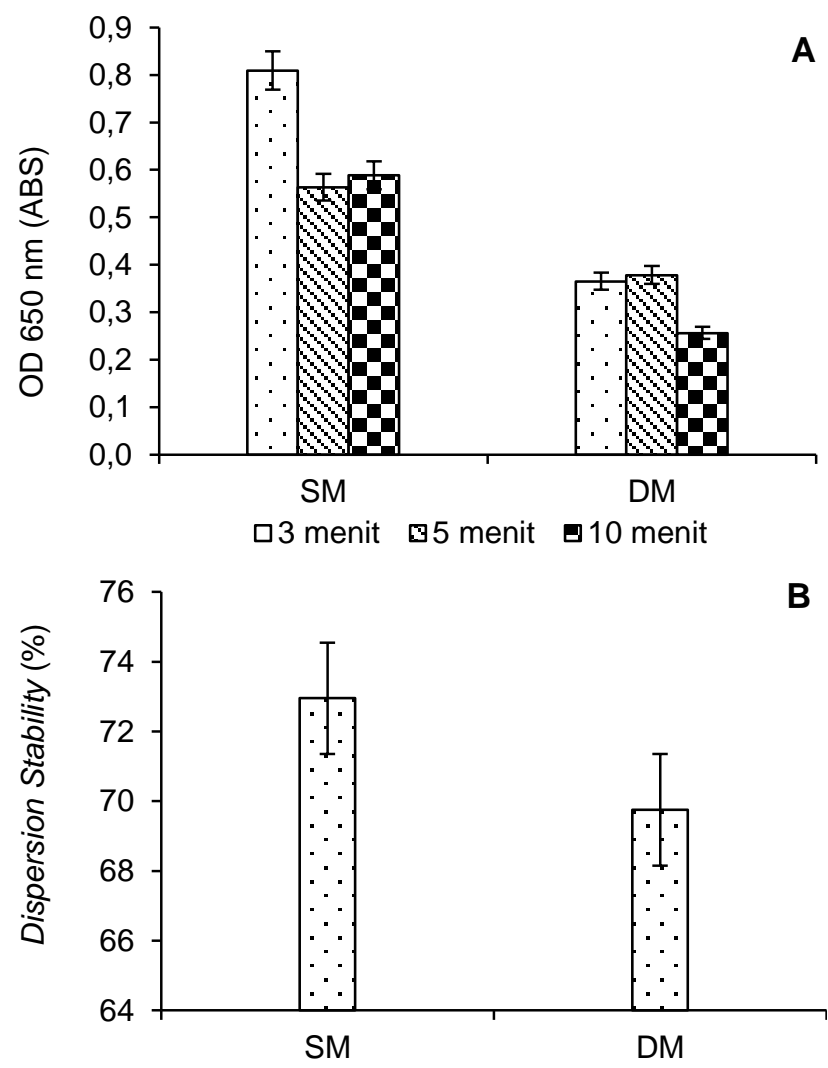

Keterangan: $\mathrm{SM}=$ Stone miller; $\mathrm{DM}=$ Disc miller

Gambar 3. Kestabilan dispersi tepung teh hijau berdasarkan waktu $(A)$ dan kestabilan relatif dispersi tepung teh hijau (B) dengan alat penepung berbeda

Gambar 3B menunjukkan kestabilan relatif dispersi (\%) dari tepung teh hijau dengan metode penepung berbeda. Kestabilan relatif dispersi dihitung merujuk pada metode yang digunakan oleh Sakurai et al. (2017) dimana berdasarkan hasil pembagian nilai absorbansi pada menit ke 10 dengan menit ke 3. Metode penepung SM memiliki kestabilan relatif dispersi lebih tinggi dengan nilai $72,95 \%$. Nilai kestabilan relatif dispersi yang tinggi disebabkan rerata ukuran partikel tepung teh hijau yang kecil dan lebih halus (Sakurai et al., 2017). Berdasarkan data yang disajikan sebelumnya, tepung teh hijau metode SM memiliki kestabilan dispersi yang tinggi (Gambar 3) dan ukuran partikel yang halus dan lebih seragam (Tabel 1). 


\section{KESIMPULAN}

Karakteristik fisik tepung teh hijau dipengaruhi oleh jenis metode penepung yang digunakan. Metode penepung SM menghasilkan ukuran partikel tepung teh hijau yang lebih kecil dan halus dengan warna hijau cerah jika dibandingkan dengan metode DM. Ukuran yang lebih kecil dan seragam dari tepung teh hijau dengan metode SM lebih sesuai jika ingin di aplikasikan pada produk pangan. Pemanfaatan dan pengembangan teknologi penepung metode SM diharapkan bisa meningkatkan kualitas tepung teh hijau yang diproduksi di Indonesia sehingga bisa mengurangi ketergantungan impor tepung teh hijau dari Jepang dan Cina.

\section{DAFTAR PUSTAKA}

Barbosa-Canovas GV, Ortega-Rivas E, Juliano P, Yan H. 2005. Food Powders: Physical ProperTies, Processing, and Functionality. 19-88. Food Engineering Series. $1^{\text {st }}$ Edition. XVI 372. Springer US Publishers. New York City, USA. DOI: 10.1007/0-387-27613-0.

Braicu C. Ladomery MR, Chedea VS, Irimie A, Berindan-Neagoe I. 2013. The relationship between the structure and biological actions of green tea catechins. Food Chem 141: 32823289. DOI: 10.1016/j.foodchem.2013.05.122.

Cuevas-Rodríguez EO, Milán-Carrillo J, Mora-Escobedo R, Cárdenas-Valenzuela OG, Reyes-Moreno C. 2004. Quality protein maize (Zea mays L.) tempeh flour through solid state fermentation process. LWT-Food Sci Tech 37: 59-67. DOI: 10.1016/S0023-6438(03)00134-8.

de Oliveira A, Prince D, Lo C.-Y, Lee LH, Chu T.-C. 2015. Antiviral activity of theaflavin digallate against herpes simplex virus type 1. Antivir Res 118: 56-67. DOI: 10.1016/j.antiviral.2015.03.0 09.

Fitzpatrick J. 2013. 12-Powder Properties in Food Production Systems. di dalam buku Handbook of food powders processes and properties. 285-308. Woodhead Publishing Cambridge, UK. DOI: 10.1533/9780857098672.2.285.

Fujioka K, Iwamoto T, Shima H, Tomaru K, Saito $H$, Ohtsuka M, Yoshidome, Kawamura Y, Manome Y. 2016. The powdering process with a set of ceramic mills for green tea promoted catechin extraction and the ROS inhibition effect. Molecules 21: 1-12. DOI: 10.3390/molecules21 040474.

Hajiaghaalipour F, Kanthimathi MS, Sanusi J, Rajarajeswaran J. 2015. White tea (Camellia sinensis) inhibits proliferation of the colon can- cer cell line, HT-29, activates caspases and protects DNA of normal cells against oxidative damage. Food Chem 169: 401-10. DOI: 10.101 6/j.foodchem.2014.07.005.

Haraguchi Y, Imada Y, Sawamura S. 2003. Production and characterization of fine Matcha for processed food. J Jpn Soc Food Sci 50: 468-473. DOI: 10.3136/nskkk.50.468.

Henning SM, Yang J, Hsu M, Lee RP, Grojean EM, Ly A, Tseng C-H, Heber D, Li, Z. 2017. Decaffeinated green and black tea polyphenols decrease weight gain and alter microbiome populations and function in diet-induced obese mice. Eur J Nutr 56: 1-11. DOI: 10.1007/s0039 4-017-1542-8.

Hirai M, Yoshikoshi H, Kitano M, Wakimizu K, Sakaida T, Yoshioka T, Nitabaru J, Nakazono K, Hayashi M, Maki, T. 2008. Production of value-added crop of green tea in summer under the shade screen net: Canopy microenvironments. Acta Hortic 797: 411-418. DOI: 10.1766 0/ActaHortic.2008.797.59.

$\mathrm{Hu}$ J, Chen Y, Ni D. 2012. Effect of superfine grinding on quality and antioxidant property of fine green tea powders. LWT-Food Sci Technol 45: 8-12. DOI: 10.1016/j.Iwt.2011.08.002.

Kavaz-Yüksel A, Yüksel M, Şat İG. 2017. Determination of certain physicochemical characteristics and sensory properties of green tea powder (matcha) added ice creams and detection of their organic acid and mineral contents. Gida/J Food 42: 116-126. DOI: 10.1523 7/gida.GD16072.

Komes D, Horzic D, Belscak A. Ganic KK, Vulic I. 2010. Green tea preparation and its influence on the content of bioactive compounds. Food Res Int 43: 167-76. DOI: 10.1016/j.foodres.200 9.09.022.

Lumay G, Boschini F, Traina K, Bontempi S, Remy JC, Cloot R, Vandewalle N. 2012. Measuring the flowing properties of powders and grains. Powder Technol 224: 19-27. DOI: 10.1016/j.po wtec.2012.02.015.

Murtini ES, Prawira-Atmaja MI, Sutrisno A. 2016. Pengaruh metode fermentasi substrat padat dan substrat terendam pada biji sorgum terhadap kualitas tepung. J Teknol Industri Pangan 27: 59-67. DOI: 10.6066/jtip.2016.27. 1.59 .

Ning JM, Hou GG, Sun JJ, Wan, XC, Dubat A. 2017. Effect of green tea powder on the quality attributes and antioxidant activity of whole-wheat flour pan bread. LWT-Food Sci Technol 79: 342-48. DOI: 10.1016/j.Iwt.2017.01.052. 
Pandey RK, Manimehalai N. 2014. Production of instant tea powder by spray drying. Int $\mathrm{J}$ Agr Food Sci Technol 5: 197-202.

Park D, Imm J, Ku K. 2001. Improved dispersibility of green tea powder by microparticulation and formulation. J Food Sci 66: 793-798. DOI: 10.1 111/j.1365-2621.2001.tb15174.x.

Pasrija D, Ezhilarasi PN, Indrani D, Anandharamakrishnan C. 2015. Microencapsulation of green tea polyphenols and its effect on incorporated bread quality. LWT-Food Sci Technol 64: 28996. DOI: 10.1016/J.LWT.2015.05.054.

Ramachandraiah K, Chin KB. 2016. Evaluation of ball-milling time on the physicochemical and antioxidant properties of persimmon by-products powder. Innov Food Sci Emerg 37: 115124. DOI: $10.1016 /$ j.ifset.2016.08.005.

Rohdiana D, Suganda AG, Wirasutisna KR, Iwo MI. 2014. Xanthine oxidase inhibitory and immunomodulatory activities of fifteen grades Indonesia orthodox black tea. Int J Pharm Pharm Sci 6: 39-42.

Sakurai Y, Mise R, Kimura S, Noguchi S, Iwao Y, Itai S. 2017. Novel method for improving the water dispersibility and flowability of fine green tea powder using a fluidized bed granulator. J Food Eng 206: 118-124. DOI: 10.1016/j.jfoodeng.201 7.03.010.

Sawamura S, Ichitani M, Ikeda H, Sonoda J. 2012. Foaming property and foam diameter of matcha varies with particle size. J Jpn Soc Food Sci 59: 109-14. DOI: 10.3136/nskkk.59.109.
Schuck P, Anne D, Jeantet R. 2012. Analytical Methods for Food and Dairy Powder. 119-189. A john Wiley \& Sons, Ltd., Publication. West Sussex, UK. DOI: 10.1017/CBO978110741532 4.004 .

Sharangi AB, Siddiqui W, Dávila Aviña JE. 2014. Black tea magic: overview of global research on human health and therapeutic potentialities. J Tea Sci Res 4: 1-16. DOI: 10.5376/jtsr.2014.0 4.0001.

Topuz A, Dinçer C, Torun M, Tontul I, ŞahinNadeem H, Haznedar A, Özdemir F. 2014. Physicochemical properties of Turkish green tea powder: Effects of shooting period, shading, and clone. Turk J Agric For 38: 233-241. DOI: 10.3906/tar-1307-17.

Zhang Z, Song H, Peng Z, Luo Q, Ming J, Zhao G. 2012. Characterization of stipe and cap powders of mushroom (Lentinus edodes) prepared by different grinding methods. J Food Eng 109: 406-413. DOI: 10.1016/j.jfoodeng.2011.11.007.

Zokti J, Sham Baharin B, Mohammed A, Abas F. 2016. Green tea leaves extract: microencapsulation, physicochemical and storage stability study. Molecules 21: 940 . DOI: $10.3390 /$ molecu les21080940.

Xiao W, Zhang Y, Fan C, Han L. 2017. A method for producing superfine black tea powder with enhanced infusion and dispersion property. Food Chem 214: 242-247. DOI: 10.1016/j.foodchem. 2016.07.096. 